\title{
A Systematic Review of Extant Literature in Social Media in the Marketing Perspective
}

\author{
Ali Abdallah Alalwan ${ }^{1}$, Nripendra P. Rana ${ }^{2}$, Raed Algharabat ${ }^{3}$, Ali Tarhini ${ }^{4}$ \\ ${ }^{1}$ Amman College of Banking and Financial Sciences, Al-Balqa' Applied University, Amman \\ Jordan \\ \{alwan.a.a.ali@gmail.com\} \\ ${ }^{2}$ School of Management, Swansea University Bay Campus, Swansea, SA1 8EN, UK \\ \{n.p.rana@swansea.ac.uk\} \\ ${ }^{3}$ The School of Business Department of Marketing, The University of Jordan \\ \{raed.algharabat@gmail.com\} \\ ${ }^{4}$ Department of Information Systems, Sultan Qaboos University, Muscat, Sultanate of \\ Oman \{Ali.Tarhini@hotmail.co.uk\}
}

\begin{abstract}
Social media applications have been extensively used and adopted by individuals and organisations in most aspects of daily life. Likewise, researchers have spent much effort in examining and exploring the effectiveness and efficiency of engaging such applications over the marketing context. This study, therefore, realizes the necessity of conducting a review of prior literature of social media over the marketing context especially in the light of the fact that only a small number of studies have been reviewed and conducted in this area. Accordingly, the aim of this study is to systematically review the current literature of social media in the marketing context. By reviewing approximately 71 articles, this study provides an overview of the main themes and trends covered by the relevant literature such as the role of social media on advertising, the electronic word of mouth, customers' relationship management, and firms' brands and performance.
\end{abstract}

Keywords: Social Media, Marketing, Systematic Review, CRM, Advertising

\section{Introduction}

Social media platforms have become an integral part of our daily life. The most human interactions have been moving to take their place over virtual platforms (i.e. Facebook, Instagram, LinkedIn and Twitter) and people are more likely to formulate a positive attitude and perception towards such technologies [12, 57, 67, 75].

By the same token, social media innovative applications (hardware and software) have been available for firms and customers worldwide and can be utilised to effectively interact with customers, create and share a sufficient content, and enhance interoperability $[6,27,35,48]$. According to [6], there are three main aspects that could differentiate social media in comparison with traditional computer-mediated communications and are summarised by [6] as follows: a) by using social media platforms, customers have more points (i.e. PC desktop, mobile phone, personal 
digital assistance, iPad) to access the targeted websites; b) more interactivity can be attained using social media to communicate with customers, and accordingly customers are more to be value creator rather than just receiver; c) the third aspect is related to the fact that by using social media, customers have more power to influence and to attain the best offers. Accordingly, social media has been largely realised as an effective mechanism that contributes to the firms' marketing aims and strategy; especially in the aspects related to customers' involvement, customer relationship management and communication [25,63].

Therefore, social media-related issues represent worth directions to be considered and examined as highly recommended by academics over the relevant area $[8,33,14$; $61]$. This could be attributed to the need to understand the feasibility of using social media over the marketing context. Such thought has been assured by [33] who highly supported the importance of examining the role of social media over different contexts to expand the existing knowledge toward such important issues of social media. As well as, in their recent review study, [25] argued that even though social media-related issues have been the focus of attention for many researchers worldwide, there is still a necessity to formulate a rigorous theoretical framework clarifying the main aspects that could hinder or contribute to such technology from either the customers' perspective or the firms' perspective.

In fact, social media-related issues have recently been the focus of attention of researchers worldwide and many studies have been conducted in this regard over different sectors, countries and from different perspectives as well [see 6, 12, 25, 48]. The marketing area has received the largest part of these studies; researchers have examined the role of social media as mentioned by [12]. It is also worth noting that different aspects and factors have been examined over the prior literature regarding social media marketing as well as different research approaches that have been applied to test such issues. Accordingly, the current study realised a necessity of conducting a systematic review of the relevant literature of social media over the marketing context to synthesise and organise the main areas covered by these studies and how these studies examined such issues.

\section{Literature of social media over the marketing context}

In line with the main aim of this study, it has been restricted to studies that have examined the role of social media over the marketing area. Accordingly, other studies that have considered the role of social media over different areas (i.e. education, social, politics, and management) have been excluded. In addition, this study was also restricted to articles published in impact factor journals written in the English language.

Indeed, over the period extending from September 2015 to January 2016, this study has started looking at the main database research engine (i.e. Sciencedirect, Emeraldinsight, EBSCO, and Google scholar) to collect the related articles. Researchers have used a number of terms to reach the relevant articles such as marketing along with social media, marketing and Web 0.2 , customers along with social media, social media marketing, and social media and branding. The researchers 
also used specific names of the most well-known social media applications: Facebook, Twitter, YouTube, Google+ along with marketing, customers, and brands terms to reach the targeted articles. Such approach to reach the most relevant articles has been adopted by [74], [25], and [22] in their review studies.

In total, 71 articles were collected. These articles were found to be in different interests and themes and therefore they were segmented in subgroups as presented in the six subsections as follows:

\subsection{Social media and advertising}

Businesses worldwide seem to be more interested in conducting their promotional and advertising campaigns through social media vehicles [70]. This is due to the ability of social media sites enhancing the interactive communication between firms and their customers. In this regard, [42] asserted the importance of considering social media as an integral hybrid component for a promotional mix. [21] demonstrated that Facebook advertising could have different aims to influence the customers' perception, awareness, knowledge, preferences, their willingness to purchase or even their actual buying behaviour. Accordingly, a good number of marketing researchers have paid attention to examine the related issues of advertising over the social media platforms [i.e. 14, 19, 42, 48, 54, 66]. Indeed, the extent to how much advertisement activities were able to reach their aims in the term of effectiveness and efficiency has been evaluated based on the customers' attitudes toward such activities [i.e. 21]. By the same token, [12] argued that so as to attain a desirable level of customer attitudes, social media advertising activities should comprise of hedonic parts to provide customers a more entertaining experience.

\subsection{Social media and electronic word of mouth}

Social media applications have empowered customers to share their own experiences with a large number of people than the old traditional ways. This makes the scope and impact of electronic word of mouth more crucial [. Therefore, there are many studies that have focused on the electronic word of mouth (e-WOM) [i.e. 16, $18,32,44,55,68]$. This could be attributed to the nature of social media as a more interactive way to share any kind of content about firms and their brands to a large number of people who use these platforms [32, 55]. For instance, [18] examined the impact of a number of factors (i.e. source, network, relationship, and message/content) on the customers' reaction and response towards word of mouth distributed by way of social media platforms. The main findings of such a study indicated that the traditional word of mouth still has more influence on customer response than those that come from the social media platforms [18]. 


\subsection{Social media and customer relationship management}

As stated by [25], [69] and [10], having a strong customer relationship largely depends on the ability of firms to emotionally and cognitively involve their customers with its brand. Recently, most companies are looking to take advantage of social media applications (i.e. Facebook, Twitter) so as to leverage customer experience as well as customer relationship management [18]. Indeed, communication, relationship development and promotion are fostered through the posting and sharing of content with consumers [e.g. 30,62] as well as through exchange and interaction facilitated through social media [23, 43, 56]. [23], [43], [30] and [62] acknowledged that levers comprised in social media platforms that enable customers and firms to commonly post, share, and interact play a highly positive role in enhancing the level of communication, customer relationship management and the efficiency of promotional activities. Over the prior literature, many marketing scholars have tested how using social media could impact the customer relationship management (CRM) (i.e. 1, 5, 7, $25,26,32,41,53,56,69,73]$.

\subsection{Social media and brand}

Several researchers [e.g. 27, Kapla35] have supported the effective role of social media in enhancing the brand's image due to its ability to tailor the messages sent according to the personal preferences of the users. Indeed, firms are able to engage their customers with their brands with a higher degree of customisation and interactivity as stated by [25]. Theoretically, many recent marketing studies that have tested brand issues over the social media platforms [i.e. 7, 11, 15; 19, 24, 27, 28, 32, $37,38,45,46,60]$. For instance, in their conference paper, [24] indicated that the customers' willingness to follow brands on social media is derived by five factors: brand affiliation, investigation, opportunity seeking, conversation, and entertainment. A qualitative study conducted by [59] who interviewed fourteen ladies in Ireland indicated that social media platforms such as Facebook and Twitter have an important role in shaping the female's perception and awareness of their needs toward online fashion brands.

\subsection{Social media and customer behavior and perception}

Indeed, as a part of their daily life, customers nowadays depend largely on the social media over the whole stages of his or her purchasing process: collecting information, conducting actual purchasing, adoption, and even in forming their attitudes and future behaviour (loyalty, commitment, retention) [41]. Therefore, social media plays an important role either in the term of helping customers to attain information required or by enabling them to create their own content and share it with others [20]. For instance, more than $20 \%$ of customers, according to [54], have a strong thought that social media is a considerable source of information when they are in the process of finalising their purchasing decision. This makes social media 
platforms one of the most important factors predicting customer behaviour and decision-making [50].

The important role of social media has been largely discussed by different researchers over the relevant area of marketing and social media [i.e. 20, 50, 54, 59, $72,73]$. For example, a recent study undertaken in the hotel context in the USA by [40] reported that customer experience with social media has an influence on consumer attitudes towards both Twitter and Facebook. Moreover, the dimensions pertaining to the high degree of interactivity and personalisation have contributed to both customers' experience as well as the information resources needed by customers in their purchasing decisions as stated by [13], [21], [31] and [50]. [72] indicated that customers' intention to purchase is significantly predicted by the role of involvement. [72] noticed that customers' involvement was largely enhanced by using social media. Three factors - enjoyment, internalisation and identification - were found by [34] to be key predictors contributing to travellers' behaviour to share their experiences on the social media platforms.

\subsection{Adoption of social media}

The related issues of adoption and usage of social media have derived an interest by marketing researchers [i.e. 9, 13, 14, 17, 28, 36, 47, 49, 65, 74]. Indeed, there are number of factors that have been tested to predict the adoption behaviour of social media platforms. For example, both perceived benefits and perceived risk have been proven to have a strong influence on the individuals' intention to use social media as reported by [47] and [49]. Customers' behaviour, intention and interactions with social media are largely influenced by website integrity, credibility and subjectivity as founded by [74]. [28] also attempted to explain the key drivers justifying why customers are willing to adopt social media applications. In this regard, three kinds of different users' behaviours related to social media adoption were identified by [28]; they are the general use of social media platforms; joining brands' page on social media; and opt on ads on the social media. To do so, [28] formulated their conceptual model based on the decomposed theory of planned behaviour. Their results strongly supported the role of attitudes, relative advantage, complexity, compatibility, and selfefficacy in shaping the adoption of social media platforms. Based on both the Technology Acceptance Model and the Resource Based Theory, [65] were able to prove the significant influence of perceived ease of use, image, and perceived barriers on the perceived usefulness pertaining to the social media.

\section{Methods adopted in examining the role of social media in the marketing context}

A closer look at the main methods implemented by researchers in examining the related issues of social media over marketing context leads the researchers to observe many approaches adopted in this area. A quantitative approach using a questionnaire survey has been commonly used by different studies [i.e. 14, 15, 23, 24, 29, 32, 43, 
72, 72]. It is also worth mentioning that most of these quantitative approaches have tested their empirical data using the Structural Equation Modelling (SEM) [i.e. 14, 24, $28,32,34]$. The qualitative approach has been largely used by researchers to explore the associated area of social media marketing (i.e. [1]). Importantly, content analyses of material posted over social media platforms were noticed to be extensively used by most qualitative studies [56]. Another group of qualitative studies [i.e. 7, 59] were found to be using the interview approach to collect the required data. The mixed method has been noticed in a number of studies [28, 53, 54]. Case studies have been considered as a suitable research approach to explore the related issues of social media by a number of marketing researchers [i.e. 36, 43]. [22], [25], [27], and [74] have used a systematic review approach of most papers and studies conducted over the related area of social media and marketing. Other parts of social media studies were found in the form of a theoretical framework and conceptual model papers (i.e. $8,51,52,58,61,68,73]$.

\section{Discussion}

By reviewing the main papers that have examined the role of social media over the marketing context, it was concluded that social media-related issues represent an emerging trend capturing more interest by practitioners and researchers. This was proved by the large number of papers that have been published between 2010 and 2016 in addition to the fact that most of these papers have been published after 2014 [i.e. $25,39,57,64,74,75]$. Such recent interest conveys a sign about the importance of examining the related issues of social media over the marketing context.

It is also worth considering that the reviewed studies have addressed different practices for social media in the marketing context and from different perspectives. For instance, a number of studies concentrated on the effective use of social media for promotion and advertising activities [i.e. 14, 19]. However, most of these studies [i.e. $42,48,66]$ recommended examining such issues of advertising by considering other factors and using different research methods as well. Further, there is still a need to see how the effectiveness of such advertising activities could be different from one platform to another (i.e. Facebook vs YouTube). In this regard, [25] did not consider the different kinds of Facebook advertising and accordingly recommended examining if different forms of Facebook advertising could reflect a variation in the customers' attitudes.

Researchers were also able to notice that considerable attention of the reviewed studies was on how firms can successfully use social media applications either in terms of e-WOM [i.e. 16, 18] or in terms of enhancing CRM [i.e. 56, 69, 73].This means that using social media for the related issues of e-WOM and CRM is critical and requires further understanding and research as recommended by [1], [5], [7], [44]. It is also important to consider how such mechanisms (personalization, interactivity, and digital community) could be accelerated using social media applications, and accordingly, contributing to both CRM and e-WOM [see 18, 25, 74].

A number of studies were found to be interested on the impacting role of social media on customers' perception and behaviour towards firms, their brands, and 
products [i.e. 15, 19, 20, 24, 27, 28]. Indeed, it was observed that such a role has been addressed differently; while some studies capture the customers' point of view regarding how social media has been an important source of information to them [i.e. 20, 54], other studies have looked at how customers' attitudes and purchasing behaviour could be predicted by social media [i.e. 40]. In this regard, as discussed by $[1,3]$ in their paper examining the adoption of mobile banking, social media tools could also be used by banks to accelerate the adoption of such emerging technologies. Therefore, another important research trend could be in testing the effective use of social media in teaching customers and enhancing their intention and adoption toward such technologies as assured by $[2,4]$.

The last important theme pertained to examining the factors predicting adoption of social media platforms [i.e. 36, 47]. Several factors have been examined to predict the customers' adoption towards such technologies such as: perceived benefits and perceived risk [47, 49]; website integrity, credibility and subjectivity [i.e. 74]. Further, quite a few of these studies have formulated their model according to well-established theories such as the Technology Acceptance Model and the Resource Based Theory [65]; and the theory of planned behaviour [28]. However, there is still a need to systematically select the related factors that could influence the adoption of social media by users. Furthermore, the theoretical foundation proposed should clearly explain the related issues of adoption of social media from the customers' perspective. In this regard, the new model by [71] could be used as this model has accurately proposed to predict the adoption of system applications from the customers' perspective as proved by [3] in their study to examine the adoption of Internet banking.

\section{Conclusion}

This study was conducted with the intention to systematically review the prior literature of social media over the marketing context. Indeed, such a review was important to be conducted to see how practitioners and researchers addressed the implications of social media for marketing issues. This study began by providing an introduction about social media and its importance from the marketing perspective. It also provided further discussion regarding the concept of social media and social media marketing. In section three, literature of social media over the marketing context, it was mentioned that such literature could be categorised into six main themes: social media and advertising; social media and e-WOM; social media and CRM; social media and brand issues; social media and customers' perception and behaviour; social media from the firms' perspective; and adoption of social media. In this study, it also looked at the main research methods and approaches adopted by studies reviewed (i.e. quantitative approach; qualitative approach; mix method questionnaire survey; content analyses; review studies). In the discussion section, it provided further explorations for the main six themes as well as what main directions were required for further examination. 


\subsection{Limitations and future research directions}

As any other reviewing studies, the current study is restricted by a number of limitations. For instance, all social media articles reviewed in the current study were over marketing context. Therefore, other kinds of social media studies over different contexts are very important to be considered as well. This study also conducted a systematic review of these studies. As mentioned in section 4, there are a good number of papers that have conducted a quantitative approach. Accordingly, future studies could easily employ a meta-analysis method to discover the most frequently and influential factors over the related studies of social media marketing. It also indicated that social media-related issues are emerging trends and there is need for further examinations and exploration, and accordingly, there is still a need to conduct more studies over different cultures and context by using different approaches.

\section{References}

1. Abreza, G., O'Reilly, N., and Reid, I.: Relationship marketing and social media in sport. International Journal of Sport Communication, 6(2), 120--142 (2013)

2. Alalwan, A. A., Dwivedi, Y., Rana, N. P., and Williams, M. D.: Consumer adoption of mobile banking in Jordan: Examining the role of usefulness, ease of use, perceived risk and self-efficacy. Journal of Enterprise Information Management, 29(1), 118--139 (2016)

3. Alalwan, A. A., Dwivedi, Y. K., and Williams, M. D.: Customers' Intention and Adoption of Telebanking in Jordan. Information Systems Management, 33(2), 154--178 (2016)

4. Alalwan, A. A., Dwivedi, Y. K., Rana, N. P., Lal, B., \& Williams, M. D.: Consumer adoption of Internet banking in Jordan: examining the role of hedonic motivation, habit, self-efficacy and trust. Journal of Financial Services Marketing, 20(2), 145--157 (2015)

5. Ballings, M., and Van den Poel, D.: CRM in social media: Predicting increases in Facebook usage frequency. European Journal of Operational Research, 244(1), 248--260 (2015)

6. Berthon, P. R., Pitt, L. F., Plangger, K., and Shapiro, D.: Marketing meets Web 2.0, social media, and creative consumers: Implications for international marketing strategy. Business Horizons, 55(3), 261--271(2012)

7. Bianchi, C., and Andrews, L.: Investigating marketing managers' perspectives on social media in Chile. Journal of Business Research, 68(12), 2552--2559(2015)

8. Billings, A.: Power in the reverberation why Twitter matters, but not the way most believe. Communication \& Sport, 2(2), 107--112 (2014)

9. Bolton, R. N., Parasuraman, A., Hoefnagels, A., Migchels, N., Kabadayi, S., Gruber, T., and Solnet, D.: Understanding generation $Y$ and their use of social media: A review and research agenda. Journal of Service Management, 24(3), 245--267 (2013)

10.Brodie, R. J., Ilic, A., Juric, B., and Hollebeek, L.: Consumer engagement in a virtual brand community: An exploratory analysis. Journal of Business Research, 66(1), 105--114 (2013)

11.Bruhn, M., Schoenmueller, V., and Schäfer, D. B.: Are social media replacing traditional media in terms of brand equity creation? Management Research Review, 35(9), 770--790 (2012)

12.Carrillat, A. F., Astous, A., and Grégoire, E. M.: Leveraging social media to enhance recruitment effectiveness: A Facebook experiment. Internet Research, 24(4), 86--123 (2014)

13.Chandra, B., Goswami, S., and Chouhan, V.: Investigating attitude towards online advertising on social media-an empirical study. Management Insight, 8(1) (2013) 
14.Chang, Y. T., Yu, H., and Lu, H. P.: Persuasive messages, popularity cohesion, and message diffusion in social media marketing. Journal of Business Research, 68(4), 777--782 (2015)

15.Christou, E.: Branding social media in the travel industry. Procedia-Social and Behavioral Sciences, 175, 607--614 (2015)

16.Chu, S. C., and Kim, Y.: Determinants of consumer engagement in electronic word-ofmouth (eWOM) in social networking sites. International Journal of Advertising, 30(1), 47-$75(2011)$

17.Clavio, G., and Kian, T. M.: Uses and gratifications of a retired female athlete's Twitter followers. International Journal of Sport Communication, 3(4), 485--500 (2010)

18.Coulter, K. S., and Roggeveen, A.: "Like it or not" - consumer responses to word-of-mouth communication in on-line social networks. Management Research Review, 35(9), 878--899 (2012)

19.De Vries, L., Gensler, S., and Leeflang, P. S.: Popularity of brand posts on brand fan pages: An investigation of the effects of social media marketing. Journal of Interactive Marketing, 26(2), 83--91 (2012)

20.Drews, W., and Schemer, C.: E-tourism for all? Online travel planning of disabled people. Information and Communication Technologies in Tourism, 507--518 (2010)

21.Duffett, R. G.: Facebook advertising's influence on intention-to-purchase and purchase amongst millennials. Internet Research, 25(4), 498--526 (2015)

22.Dwivedi, Y. K., Kapoor, K. K., and Chen, H.: Social media marketing and advertising. The Marketing Review, 15(3), 289--309 (2015)

23.Eagleman, A. N.: Acceptance, motivations, and usage of social media as a marketing communications tool amongst employees of sport national governing bodies. Sport Management Review, 16(4), 488--497 (2013)

24.Enginkaya, E., and Yilmaz, H. What drives consumers to interact with brands through social media? A motivation scale development study. Procedia-Social and Behavioral Sciences, 148, 219--226 (2014)

25.Filo, K., Lock, D., and Karg, A.: Sport and social media research: A review. Sport Management Review, 18(2), 166--181 (2015)

26.Gamboa, A. M., and Gonçalves, H. M.: Customer loyalty through social networks: Lessons from Zara on Facebook. Business Horizons, 57(6), $709--717$ (2014)

27.Gensler, S., Völckner, F., Liu-Thompkins, Y., and Wiertz, C.: Managing brands in the social media environment. Journal of Interactive Marketing, 27(4), 242--256 (2013)

28.Gironda, J. T., and Korgaonkar, P. K.: Understanding consumers' social networking site usage. Journal of Marketing Management, 30(5-6), 571--605 (2014)

29.Gummerus, J., Liljander, V., Weman, E., and Pihlström, M.: Customer engagement in a Facebook brand community. Management Research Review, 35(9), 857--877 (2012)

30.Hambrick, M. E.: Six degrees of information: Using social network analysis to explore the spread of information within sport social networks. International Journal of Sport Communication, 5(1), 16--34 (2012)

31.He, W., and Zha, S. Insights into the adoption of social media mashups. Internet Research, 24(2), 160--180 (2014)

32.Hudson, S., Huang, L., Roth, M. S., and Madden, T. J.: The influence of social media interactions on consumer-brand relationships: A three-country study of brand perceptions and marketing behaviors. International Journal of Research in Marketing, in press (2015)

33. Hutchins, B.: Twitter follow the money and look beyond sports. Communication \& Sport, 2, 122--126 (2014)

34.Kang, M., and Schuett, M. A.: Determinants of sharing travel experiences in social media. Journal of Travel \& Tourism Marketing, 30(1/2), 93--107 (2013)

35.Kaplan, A. M., and Haenlein, M.: Users of the world, unite! The challenges and opportunities of social media. Business Horizons, 53(1), 59--68 (2010) 
36.Killian, G., and McManus, K. A.: marketing communications approach for the digital era: Managerial guidelines for social media integration. Business Horizons, 58(5), 539--549 (2015)

37.Kim, A. J., and Ko, E.: Do social media marketing activities enhance customer equity? An empirical study of luxury fashion brand. Journal of Business Research, 65(10), 1480--1486 (2012)

38.Kim, S., Koh, Y., Cha, J., and Lee, S.: Effects of social media on firm value for US restaurant companies. International Journal of Hospitality Management, 49, 40--46 (2015)

39.Leeflang, P. S., Verhoef, P. C., Dahlström, P., and Freundt, T.: Challenges and solutions for marketing in a digital era. European Management Journal, 32(1), 1--12 (2014)

40.Leung, X. Y., Bai, B., and Stahura, K. A.: The marketing effectiveness of social media in the hotel industry a comparison of Facebook and Twitter. Journal of Hospitality \& Tourism Research, 39(2), 147--169 (2015)

41.Malthouse, E. C., Haenlein, M., Skiera, B., Wege, E., and Zhang, M.: Managing customer relationships in the social media era: Introducing the social CRM house. Journal of Interactive Marketing, 27(4), 270--280 (2013)

42.Mangold, W. G., and Faulds, D. J.: Social media: The new hybrid element of the promotion mix. Business Horizons, 52(4), 357--365 (2009)

43.McCarthy, J., Rowley, J., Jane Ashworth, C., and Pioch, E.: Managing brand presence through social media: the case of UK football clubs. Internet Research, 24(2), 181--204 (2014)

44.Munar, A. M., and Jacobsen, J. K. S.: Trust and involvement in tourism social media and web-based travel information sources. Scandinavian Journal of Hospitality and Tourism, 13(1), 1--19 (2013)

45.Naylor, R. W., Lamberton, C. P., and West, P. M.: Beyond the "like" button: The impact of mere virtual presence on brand evaluations and purchase intentions in social media settings. Journal of Marketing, 76(6), 105--120 (2012)

46. Nguyen, B., Yu, X., Melewar, T. C., and Chen, J.: Brand innovation and social media: Knowledge acquisition from social media, market orientation, and the moderating role of social media strategic capability. Industrial Marketing Management, 51, $11--25$ (2015)

47.Nusair, K. K., Bilgihan, A., Okumus, F., and Cobanoglu, C.: Generation Y travelers' commitment to online social network websites. Tourism Management, 35, 13--22 (2013)

48.Okazaki, S., and Taylor, C. R.: Social media and international advertising: Theoretical challenges and future directions. International Marketing Review, 30(1), 56--71 (2013)

49.Parra-López, E., Bulchand-Gidumal, J., Gutiérrez-Taño, D., and Díaz-Armas, R.: Intentions to use social media in organizing and taking vacation trips. Computers in Human Behavior, 27(2), 640--654 (2011)

50. Patino, A., Pitta, D. A., and Quinones, R.: Social media's emerging importance in market research. Journal of Consumer Marketing, 29(3), 233--237 (2012)

51.Pedersen, P. M.: A commentary on social media research from the perspective of a sport communication journal editor. Communication \& Sport, 2, 138--142 (2014)

52.Pegoraro, A.: Twitter as disruptive innovation in sport communication. Communication \& Sport, 2, 132--137 (2014)

53.Pereira, H. G., de Fátima Salgueiro, M., and Mateus, I.: Say yes to Facebook and get your customers involved! Relationships in a world of social networks. Business Horizons, 57(6), 695--702 (2014)

54.Powers, T., Advincula, D., Austin, M. S., Graiko, S., and Snyder, J.: Digital and social media in the purchase decision process. Journal of Advertising Research, 52(4), 479--489 (2012)

55.Priyanka, S.: A study of online advertising on consumer behaviour. International Journal of Engineering and Management Science, 3(4), 461--465 (2013) 
56.Pronschinske, M., Groza, M. D., and Walker, M.: Attracting Facebook 'fans': The importance of authenticity and engagement as a social networking strategy for professional sport teams. Sport Marketing Quarterly, 21(4), 221--231 (2012)

57.Rathore, A. K., Ilavarasan, P. V., and Dwivedi, Y.: Social media content and product co-creation: An emerging paradigm. Journal of Enterprise Information Management, 29(1), 7--18 (2016)

58.Rowe, D.: Following the followers sport researchers' labour lost in the twittersphere? Communication \& Sport, 2, 117--121 (2014)

59.Ruane, L. and Wallace, E.: Generation Y females online: insights from brand narratives. Qualitative Market Research: An International Journal, 16 (3), 315--335 (2013)

60.Saboo, A. R., Kumar, V., and Ramani, G.: Evaluating the impact of social media activities on human brand sales. International Journal of Research in Marketing, In press (2015)

61.Sanderson, J.: What do we do with Twitter? Communication \& Sport. Sage Journals (2014)

62.Sanderson, J., and Hambrick, M. E.: Covering the scandal in 140 characters: A case study of Twitter's role in coverage of the Penn State saga. International Journal of Sport Communication, 5(3), 384--402 (2012)

63.Saxena, A., and Khanna, U.: Advertising on social network sites: A structural equation modelling approach. Vision: The Journal of Business Perspective, 17(1), 17--25 (2013)

64.Shilbury, D., Westerbeek, H., Quick, S., Funk, D., and Karg, A.: Strategic Sport Marketing (4th edn.) Sydney: Allen \& Unwin (2014)

65.Siamagka, N. T., Christodoulides, G., Michaelidou, N., and Valvi, A.: Determinants of social media adoption by B2B organizations. Industrial Marketing Management, 51, 89--99 (2015)

66.Steyn, P., Ewing, M. T., Van Heerden, G., Pitt, L. F., and Windisch, L.: From whence it came: Understanding source effects in consumer-generated advertising. International Journal of Advertising, 30(1), 133--160 (2011)

67.Taylor, D. G., Lewin, J. E., and Strutton, D.: Friends, fans, and followers: Do ads work on social networks? How gender and age shape receptivity. Journal of Advertising Research, 51 (1), 258--276 (2011)

68.Tham, A., Croy, G., and Mair, J.: Social media in destination choice: Distinctive electronic word-of-mouth dimensions. Journal of Travel \& Tourism Marketing, 30(1-2), 144--155 (2013)

69.Trainor, K. J., Andzulis, J. M., Rapp, A., and Agnihotri, R.: Social media technology usage and customer relationship performance: A capabilities-based examination of social CRM. Journal of Business Research, 67(6), 1201--1208 (2014)

70.Tuten, T. L., and Solomon, M. R.: Social Media Marketing. 2nd edn. Sage (2015)

71.Venkatesh, V., Thong, J. Y., and Xu, X.: Consumer acceptance and use of information technology: extending the unified theory of acceptance and use of technology. MIS quarterly, 36(1), 157--178 (2012)

72. Wang, X., Yu, C., and Wei, Y.: Social media peer communication and impacts on purchase intentions: A consumer socialization framework. Journal of Interactive Marketing, 26(4), 198--208 (2012)

73.Williams, J., and Chinn, S.: Meeting relationship-marketing goals through social media: A conceptual model for sport marketers. International Journal of Sport Communication, 3(4), 422--437 (2010)

74.Zeng, B., and Gerritsen, R.: What do we know about social media in tourism? A review. Tourism Management Perspectives, 10, 27--36 (2014)

75.Zhu, Y. Q., and Chen, H. G.: Social media and human need satisfaction: Implications for social media marketing. Business Horizons, 58(3), 335--345 (2015) 